\title{
Palliative Care Education to Enhance Informal Caregivers' Skills in Caring for Patients with Cancer: A Scoping Review
}

\author{
Christantie Effendy ${ }^{1 *}$ (D), Endar Kurianto ${ }^{2}$, Anisa Rayu Ike Darmayanti ${ }^{2,3}$, Uki Noviana ${ }^{4}$, Intansari Nurjannah ${ }^{4}$ (D) \\ ${ }^{1}$ Department of Medical Surgical Nursing, Faculty of Medicine, Public Health and Nursing, Universitas Gadjah Mada, Yogyakarta, \\ Indonesia; ${ }^{2}$ Master of Nursing Program, Faculty of Medicine, Public Health and Nursing, Universitas Gadjah Mada, Yogyakarta, \\ Indonesia; ${ }^{3} \mathrm{Dr}$. Sardjito Hospital, Yogyakarta, Indonesia; ${ }^{4}$ Department of Mental Health and Community Nursing, Faculty of \\ Medicine, Public Health and Nursing, Universitas Gadjah Mada, Yogyakarta, Indonesia
}

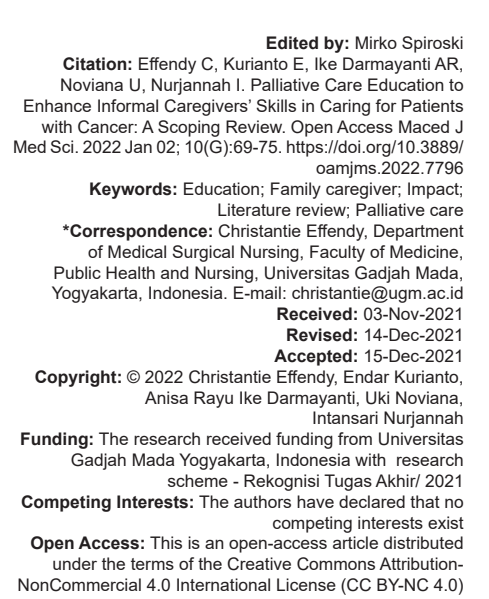

\section{Abstract}

BACKGROUND: Living with cancer causes stress for both patients and caregivers. Empowering family caregivers is critical in palliative care. It is well known that a lack of proper knowledge and training of informal caregivers is a barrier to palliative care provision at home.

AIM: This scoping review aimed to explore palliative care education to enhance informal caregiver skills in caring for a cancer patient.

METHODS: A scoping literature review was conducted with systematic searches in multiple databases - PubMed Cochrane, PsycINFO, and SCOPUS (2000-2021). Studies were selected based on programs content and its impact evaluation.

RESULTS: The remaining 181 citations were examined at full-text level; 173 studies did not meet inclusion criteria, yielding eight included papers. Four papers focused on palliative care educational programs for family caregivers, and four papers included patients and caregivers. There was a diverse variation in the mode of delivery and duration of educational input. The programs offered an insight into the main elements of working with individuals in a palliative care bundle. Most studies reported participants improved their knowledge, self-efficacy, and competency and prepared for their roles.

CONCLUSION: The findings show the need for family caregivers for more regular and reliable palliative education programs. Randomized controlled trials with rigorous randomization processes, more significant sample numbers and more appropriate control groups focused explicitly on caregiver education may improve the evidence.

\section{Introduction}

Living with cancer causes stress for both patients and caregivers [1]. Patients suffer from disease burden, while caregivers suffer from the stress of caring for a loved one with a life-threatening condition. Many cancer patients will depend on family and friends (hence referred to as "caregivers") to help them care. Cancer caregivers express physical and emotional exhaustion [2]. Many caregivers report feeling under-prepared when dealing with cancer symptoms [3], [4]. A lack of confidence and competence may exacerbate caregivers' distress in offering the complex care [5], [6]. When caregivers' psychological well-being suffers, patients' well-being suffers as well [7]. When caregivers' psychological wellbeing is impaired, patients' well-being also worsens [7].

Empowering family caregivers is critical in palliative care. There is broad agreement regarding caregivers' knowledge gaps, abilities, and attitudes [8], [9]. It is well established that a lack of proper knowledge and training is a barrier to palliative care integration [10]. The World Health Organization (WHO) has recommended that palliative care be integrated into existing healthcare systems, using the Public Health Model as a starting point [11]. The education of healthcare staff and the public is one of these model components. Other international organizations, such as the European Association of Palliative Care (EAPC), have previously emphasized the necessity of education and including the family caregiver issue [12], [13]. These guidelines should optimize health care, provide tools for best practices, and expand caregivers' knowledge on critical issues. They should pay attention to the family and the role it plays. This could help family caregivers and healthcare professionals avoid stress or burnout [14].

Numerous research studies on palliative care have been conducted. However, research findings are worthless unless they are put into action. It is generally established that active teaching methods, such as teaching evidence-based practice, can result in higher levels of engagement than some traditional 
methods [15]. Furthermore, the effectiveness of interventions is often judged by the study quality rather than the influence on caregivers" and patients' health [16]. Its effect must be evaluated and monitored regularly. The significance of the family caregiver subject is well understood in academia. However, it is uncertain whether or not it has been offered in the educational field [17]. Overall, the purpose of this integrative literature review has been to explore palliative care education to enhance informal caregiver skills in caring for terminally ill patients, highlighting the approach to the topic of family caregivers and how it has been discussed. This review is part of a larger initiative that focuses on informal caregiver education and training.

\section{Methods}

The Preferred Reporting Items defined the reporting of this review for Systematic Reviews and Meta-Analyses (PRISMA) standards [18], [19]. This scoping review employed a framework developed by [20] and an integrated method to collect primary data from various study types: randomized and nonrandomized trials with or without comparison groups; qualitative, quantitative, and mixed-method.

\section{Inclusion criteria}

Only published research was considered, and the study period was confined from January 1, 2000, to August 1, 2021. English and Indonesian language restrictions were applied. The inclusion criteria were: (1) The study included oncology-diagnosed children, adolescents, and young adults as well as their families. (2) Describe a specific education program on palliative or end-of-life care. (3) the outcome was caregiver skill in caring for cancer patients in the terminal stage.

\section{Searching strategies}

Four databases were used in the search: PubMed, Cochrane, PsycINFO, and SCOPUS (20002021). Search terms were using indexed MeSH terms, included "palliative care" OR "palliative" OR "hospice" OR "end of life" AND "education" OR "training" OR "teaching" AND "family" OR "caregivers." The search strategies were screened independently by two reviewers. The most recent search was conducted on August 1, 2021. Additional studies were checked in the reference lists of all included studies. The research team evaluated the risk of bias and assigned a quality rating to each paper based on a criterion specific to the study type (Table 1). In defining their contribution to the data synthesis, all included research were given equal consideration.
Two reviewers separately assessed eligibility at the abstract level using a pre-defined eligibility checklist. With 96\% inter-rater agreement, these independent reviewers came to a consensus on the decision to exclude or include a study with $96 \%$ interrater agreement. Six articles were discussed to obtain a consensus on their inclusion or deletion. Non-duplicate articles from references of included research with group consensus have been added. The articles were then assessed by a team of reviewers who went over the entire text systematically.

It should be noted that members of the research team did not serve as reviewers for articles that they had published. Two team members independently examined the identical published work, with an interrater agreement of $94 \%$ on the exclusion/inclusion decision. Two articles were discussed for agreement, and two of them required further clarification from the principal authors before an agreement could be reached on a consensus.

\section{Data extraction}

The researchers created a data extraction sheet (Table 1), tested it on five randomly chosen included articles. The extraction sheet contained the following information: author, country, study design and target audience, mode of delivery, strategies and duration, content, evaluation method, measures, and impact on health care professionals. Each reviewer inserted data into an online extraction template created by two study team members to ensure consistent data formats. Two study team members completed the data extraction sheet separately for each study. At least one additional team member examined data extraction to identify different viewpoints and secondary reviewers for agreement.

\section{Risk of bias assessment}

Reviewers were provided with an electronic folder including typical bias criteria for quality assessment ratings. Each reviewer examined the criteria for risk of bias in nonrandomized trials using the Effective Public Health Project tool (www.ephpp. ca/tools.html), developed by the Effective Public Health Project. Reviewers used the Consolidated Criteria for Reporting Qualitative Research criteria to analyze qualitative research for bias [18] and additional studies with reporting following Critical Appraisal Skills Programme standards (http://www. caspinternational.org/?o=1020). The funding source and the author's acknowledgment of potential bias were investigated. 
Table 1: Characteristics of included studies

\begin{tabular}{|c|c|c|c|c|c|c|c|}
\hline Author, country & $\begin{array}{l}\text { Study design and } \\
\text { Target audience }\end{array}$ & $\begin{array}{l}\text { Mode of delivery, strategies } \\
\text { and duration }\end{array}$ & Content & $\begin{array}{l}\text { Evaluation } \\
\text { method }\end{array}$ & Measures & $\begin{array}{l}\text { Impact on health care } \\
\text { professionals }\end{array}$ & $\begin{array}{l}\text { Risk of } \\
\text { bias }\end{array}$ \\
\hline $\begin{array}{l}\text { Bender et al., } \\
2020 \\
\text { Canada }\end{array}$ & $\begin{array}{l}\text { Explanatory } \\
\text { mixed-method study } \\
\text { design } \\
\text { Survivors and } \\
\text { caregivers }\end{array}$ & $\begin{array}{l}\cdot 24 \mathrm{~h} \text { of self-study, facilitated } \\
\text { online discussion, and } \\
\text { collaborative activities } \\
\text { - Blended learning over a } \\
\text { period of } 6 \text { weeks (modules } \\
1 \text { and } 2 \text { occurred in week } 1 \text { ) } \\
\text { - Homework for each module }\end{array}$ & $\begin{array}{l}\text { Peer navigator training program } \\
\text { (PNTP). } \\
\text { (1) The peer navigator role, } \\
\text { functions, and boundaries } \\
\text { (2) The care pathway and barriers } \\
\text { to care } \\
\text { (3) Social inequities and patient } \\
\text { barriers } \\
\text { (4) Information and support } \\
\text { resources } \\
\text { (5) Enhancing communication } \\
\text { skills (e.g., active listening) } \\
\text { (6) Advanced communication and } \\
\text { helping skills (e.g., motivational } \\
\text { interviewing) } \\
\text { (7) Ethics, privacy, and } \\
\text { confidentiality; and } \\
\text { (8) eHealth literacy and } \\
\text { health information and } \\
\text { communication technology }\end{array}$ & Post-test & $\begin{array}{l}\text { - Questionnaires included } \\
\text { questions pertaining to } \\
\text { understanding of learning } \\
\text { objectives } \\
\text { - Self-efficacy for core } \\
\text { competencies } \\
\text { - eHealth literacy }\end{array}$ & $\begin{array}{l}\text { A blended learning course } \\
\text { is feasible and acceptable } \\
\text { to PC survivors and } \\
\text { caregivers and effective in } \\
\text { increasing knowledge and } \\
\text { competency for the peer } \\
\text { navigator role }\end{array}$ & $\begin{array}{l}\text { Low } \\
\text { risk }\end{array}$ \\
\hline $\begin{array}{l}\text { Kizza et al., } \\
2018 \\
\text { Uganda }\end{array}$ & $\begin{array}{l}\text { - Pre/post-test de } \\
\text { - Posit-testily } \\
\text { caregivers }\end{array}$ & $\begin{array}{l}\text { First component } \\
\text { - One-on-one training } \\
\text { sessions (each lasting } \\
45-60 \text { min) } \\
\text { - Booklet Second component } \\
\text { - Each FGC was visited } \\
\text { once every } 4 \text { weeks for a } \\
\text { period of } 12 \text { weeks } \\
\text { - The PSVs, using } \\
\text { step-by-step approach } \\
\text { as guided by the study } \\
\text { algorithm, held simple } \\
\text { focused discussions on the } \\
\text { current ACPs' condition and } \\
\text { pain status, and checked } \\
\text { on the FCGs' progress with } \\
\text { the caregiving role and pain } \\
\text { management }\end{array}$ & $\begin{array}{l}\text { FGC included two components; } \\
\text { • Two interactive one-on-one } \\
\text { training sessions. The content } \\
\text { on characteristics and } \\
\text { sources of cancer pain and } \\
\text { management principles focused } \\
\text { on details of cancer pain } \\
\text { assessment and management, } \\
\text { and concepts such as addiction, } \\
\text { tolerance, drug abuse, and } \\
\text { dependence, "around-the-clock" } \\
\text { and "as-needed' treatment } \\
\text { - The second component of the } \\
\text { intervention that included three } \\
\text { follow-up support home visits } \\
\text { was conducted by a single peer } \\
\text { support volunteer (PSV) }\end{array}$ & Post-test & $\begin{array}{l}\cdot \text { Cancer Caregiver } \\
\text { Self-Efficacy scale } \\
\text { - Katz Index of } \\
\text { independence } \\
\text { - in activities of daily living } \\
\text { - Family Pain } \\
\text { - Questionnaire }\end{array}$ & $\begin{array}{l}\text { The FCGs' knowledge } \\
\text { and self-efficacy for pain } \\
\text { management increased } \\
\text { significantly after the } \\
\text { intervention. Conducting } \\
\text { the education intervention } \\
\text { in the FCGs and ACPs' } \\
\text { home setting was a } \\
\text { safe, affordable, and } \\
\text { an effective approach } \\
\text { to supporting and } \\
\text { empowering the FCGs, } \\
\text { and enhancing access } \\
\text { to quality cancer pain } \\
\text { management }\end{array}$ & $\begin{array}{l}\text { Low } \\
\text { risk }\end{array}$ \\
\hline $\begin{array}{l}\text { Forbat et al., } \\
2017 \\
\text { Australia }\end{array}$ & $\begin{array}{l}\text { - Single-arm } \\
\text { mixed-method } \\
\text { feasibility } \\
\text { proof-of-concept } \\
\text { trial } \\
\text { - Informal caregivers }\end{array}$ & $\begin{array}{l}\text { - The package was delivered } \\
\text { in hard copy (handbooks } \\
\text { and DVDs, not online) }\end{array}$ & $\begin{array}{l}\text { PalliativE Caregivers Education } \\
\text { Package (PrECEPt) consisted } \\
\text { of two modules identified as } \\
\text { priorities in the palliative literature } \\
\text { on caregiver needs: nutrition/ } \\
\text { hydration and pain management }\end{array}$ & & $\begin{array}{l}\text { - Self-efficacy, measured } \\
\text { using the CaSES tool } \\
\text { - Cancer Caregiving Tasks, } \\
\text { Consequences } \\
\text { - Needs Questionnaire } \\
\text { (CaTCoN) } \\
\text { - The Preparedness for } \\
\text { Caregiving Scale }\end{array}$ & $\begin{array}{l}\text { This innovative } \\
\text { approach used distance } \\
\text { learning to overcome } \\
\text { the shortcomings of } \\
\text { face-to-face delivery. } \\
\text { Without relying on Internet } \\
\text { access or travel to group } \\
\text { sessions, the approach } \\
\text { offers equitable learning } \\
\text { opportunities which can be } \\
\text { used by careers wherever } \\
\text { they live. The approach } \\
\text { enabled caregivers to feel } \\
\text { more prepared for their role }\end{array}$ & $\begin{array}{l}\text { Low } \\
\text { risk }\end{array}$ \\
\hline $\begin{array}{l}\text { Hendrix et al., } \\
2016 \\
\text { USA }\end{array}$ & $\begin{array}{l}\text { - Two-armed, } \\
\text { randomized } \\
\text { controlled trial } \\
\text { - Patients and } \\
\text { caregivers }\end{array}$ & $\begin{array}{l}\text { - The manualized training } \\
\text { followed a structured } \\
\text { topical outline with standard } \\
\text { activities for each teaching } \\
\text { area } \\
\text { - The training lasted one to } 2 \\
\text { h and, if desired, caregivers } \\
\text { could spread this out over } \\
\text { two sessions }\end{array}$ & $\begin{array}{l}\text { Enhanced caregiver (CT) training } \\
\text { has two components: management } \\
\text { of patient symptoms and caregiver } \\
\text { stress management }\end{array}$ & Post-test & $\begin{array}{l}\text { - Caregiver self-efficacy } \\
\text { - The Preparedness for } \\
\text { Caregiving scale } \\
\text { - Profile of Mood States } \\
\text { (POMS) anxiety sub-scale } \\
\text { - The Rapid Estimate of Adult } \\
\text { Literacy in Medicine }\end{array}$ & $\begin{array}{l}\text { Caregivers in the } \\
\text { Enhanced-CT group } \\
\text { had significant increases } \\
\text { in self-efficacy for } \\
\text { managing patients' cancer } \\
\text { symptoms and stress, and } \\
\text { preparedness for caregiving } \\
\text { immediately after training. A } \\
\text { caveat for implementation, } \\
\text { however, is the additional } \\
\text { time required for this } \\
\text { training that consequently } \\
\text { will require re-examination } \\
\text { of nurse workload }\end{array}$ & $\begin{array}{l}\text { Low } \\
\text { risk }\end{array}$ \\
\hline $\begin{array}{l}\text { Lee et al., } 2016 \\
\text { Taiwan }\end{array}$ & $\begin{array}{l}\text { - A two-group } \\
\text { comparative design } \\
\text { with repeated } \\
\text { measures } \\
\text { - Caregivers }\end{array}$ & $\begin{array}{l}\text {-30-40-min face-to-face } \\
\text { sessions at approximately } \\
\text { 2-week intervals until the } \\
\text { patients' death } \\
\text { - Self-efficiency of caregivers } \\
\text { was evaluated and } \\
\text { re-directed by interviews } \\
\text { - Every } 2 \text { weeks, and a } \\
\text { telephone call was made } \\
\text { every other week } \\
\text { - 4-h training program }\end{array}$ & $\begin{array}{l}\text { Integrated caregiver support } \\
\text { program that included coping } \\
\text { strategies, assistance, recourses, } \\
\text { and education (CARE) } \\
\text { 1. Develop an individual care guide } \\
\text { for FCs } \\
\text { 2. Provide education regarding } \\
\text { symptom management, including } \\
\text { symptom monitoring, symptom } \\
\text { control, hospice care, ADL support } \\
\text { 3. Help to relieve patient suffering } \\
\text { (physical, psychological, and } \\
\text { spiritual sign and symptoms.) } \\
\text { 4. Help to find support system of } \\
\text { families } \\
\text { 5. Improve communication and } \\
\text { negotiation and reduce conflict } \\
\text { within families } \\
\text { 6. Enhance problem-solving skills }\end{array}$ & Post-test & $\begin{array}{l}\text { - Caregiver Self-efficacy } \\
\text { Scale }\end{array}$ & $\begin{array}{l}\text { The caregiver support } \\
\text { intervention can increase } \\
\text { caregiver self-efficacy } \\
\text { and reduce the subjective } \\
\text { caregiving burden in } \\
\text { the } 3 \text { months before } \\
\text { the death of advanced } \\
\text { cancer patients. The } \\
\text { intervention is, therefore, } \\
\text { an appropriate strategy } \\
\text { for supporting caregivers } \\
\text { in the last } 3 \text { months of a } \\
\text { patient's life }\end{array}$ & $\begin{array}{l}\text { Low } \\
\text { risk }\end{array}$ \\
\hline
\end{tabular}


Table 1: (Continued)

\begin{tabular}{|c|c|c|c|c|c|c|c|}
\hline Author, country & $\begin{array}{l}\text { Study design and } \\
\text { Target audience }\end{array}$ & $\begin{array}{l}\text { Mode of delivery, strategies } \\
\text { and duration }\end{array}$ & Content & $\begin{array}{l}\text { Evaluation } \\
\text { method }\end{array}$ & Measures & $\begin{array}{l}\text { Impact on health care } \\
\text { professionals }\end{array}$ & $\begin{array}{l}\text { Risk of } \\
\text { bias }\end{array}$ \\
\hline $\begin{array}{l}\text { Marshall et al., } \\
2013 \\
\text { USA }\end{array}$ & $\begin{array}{l}\text { - Pre- to post-test } \\
\text { - Sport-testor } \\
\text { co-survivors }\end{array}$ & $\begin{array}{l}\text { - Each class consisted of } \\
3 \mathrm{~h} \text { of informational and } \\
\text { skill-building modules or } \\
\text { sessions } \\
\text { - Class time was also } \\
\text { allocated for demonstration } \\
\text { and practice of } \\
\text { communication and } \\
\text { problem-solving skills, and } \\
\text { providing emotional support } \\
\text { - Classes were held in } \\
\text { participant homes and other } \\
\text { natural gathering places } \\
\text { such as public libraries, } \\
\text { public health clinics serving } \\
\text { underinsured and uninsured } \\
\text { patients, and public schools }\end{array}$ & $\begin{array}{l}\text { Classes were delivered } \\
\text { collaboratively by a trained } \\
\text { counselor and a promotor, and } \\
\text { provided } \\
\text { a) Evidence-based cancer } \\
\text { information about coping with } \\
\text { cancer and caregiving } \\
\text { b) Explanation of depression } \\
\text { as a treatable illness and not } \\
\text { unexpected with cancer, and } \\
\text { c) Information about the risks of } \\
\text { breast cancer }\end{array}$ & Post-test & $\begin{array}{l}\text { - Cancer Knowledge } \\
\text { Questionnaire } \\
\text { - Efficacy regarding cancer } \\
\text { knowledge }\end{array}$ & $\begin{array}{l}\text { By making informed, } \\
\text { evidence-based, culturally } \\
\text { relevant cancer-related } \\
\text { information and support } \\
\text { more readily accessible } \\
\text { to family members, } \\
\text { health care providers } \\
\text { may reduce stress felt by } \\
\text { co-survivors and enable } \\
\text { them to more readily and } \\
\text { effectively assist their } \\
\text { loved ones with cancer }\end{array}$ & $\begin{array}{l}\text { Low } \\
\text { risk }\end{array}$ \\
\hline $\begin{array}{l}\text { Hendrix et al., } \\
2013 \\
\text { USA }\end{array}$ & $\begin{array}{l}\text { - Pre- to post-test } \\
\text { - Cost-testpatient } \\
\text { dyads }\end{array}$ & $\begin{array}{l}\text { - The program was } \\
\text { manualized, including a } \\
\text { book for caregivers } \\
\text { - The caregiver training } \\
\text { followed a structured } \\
\text { topical outline with } \\
\text { standard activities for each } \\
\text { teaching area }\end{array}$ & $\begin{array}{l}\text { The intervention provided } \\
\text { caregivers training on strategies } \\
\text { for managing patients' cancer } \\
\text { symptoms, with four major } \\
\text { components: prevention } \\
\text { of infection, pain control, } \\
\text { maintenance of nutrition, and } \\
\text { adequate elimination }\end{array}$ & Post-test & $\begin{array}{l}\text { - Lorig's self-efficacy scale. } \\
\text { - Caregiver psychological } \\
\text { well-being }\end{array}$ & $\begin{array}{l}\text { Caregiver self-efficacy } \\
\text { in-home care and } \\
\text { symptom management } \\
\text { significantly increased } \\
\text { after receiving an } \\
\text { individualized caregiver } \\
\text { training. The increase in } \\
\text { self-efficacy appeared } \\
\text { to have been sustained } \\
\text { after } 4 \text { weeks of patient's } \\
\text { hospital discharge. } \\
\text { This study finding has } \\
\text { important implications } \\
\text { on how nurses prepare } \\
\text { patients and their } \\
\text { caregivers for hospital } \\
\text { discharge }\end{array}$ & $\begin{array}{l}\text { Low } \\
\text { risk }\end{array}$ \\
\hline $\begin{array}{l}\text { Hudson et al., } \\
2009 \\
\text { Australia }\end{array}$ & $\begin{array}{l}\text { - Mixed method } \\
\text { - Primary family } \\
\text { carers of patients } \\
\text { with advanced } \\
\text { cancer }\end{array}$ & $\begin{array}{l}\text { - The education sessions } \\
\text { were semi-structured } \\
\text { and included a mix of } \\
\text { presentation and group } \\
\text { work } \\
\text { - Carers received a copy of a } \\
\text { Carer Guidebook designed } \\
\text { specifically for preparing } \\
\text { family carers for the role of } \\
\text { supporting a dying relative } \\
\text { - The CGEP incorporated } \\
\text { three sessions (1.5 heach) } \\
\text { over a 3-week period } \\
\text { - The CGEP was designed } \\
\text { for a minimum of four and } \\
\text { maximum of eight carers }\end{array}$ & $\begin{array}{l}\text { The main content of the Carer } \\
\text { Group Education Program } \\
\text { (CGEP) was based on a } \\
\text { psycho-educational intervention } \\
\text { with individual } \\
\text { home-based family carers. } \\
\text { (1) the typical role of a carer in the } \\
\text { palliative care context, including } \\
\text { an overview of the services } \\
\text { available from the palliative care } \\
\text { team, local doctor, and other } \\
\text { support services; } \\
\text { (2) strategies for self-care (carer } \\
\text { well-being) and for their } \\
\text { relative/friend (e.g., symptom } \\
\text { management); and } \\
\text { (3) strategies or caring for a person } \\
\text { when death is approaching, } \\
\text { and overview of bereavement } \\
\text { supports for the family carer }\end{array}$ & Post-test & $\begin{array}{l}\text { - Carer Competence } \\
\text { - Scale; Preparedness for } \\
\text { Caregiving } \\
\text { - Scale; Family Inventory } \\
\text { of Need; } \\
\text { - Rewards for Caregiving } \\
\text { Scale }\end{array}$ & $\begin{array}{l}\text { Participants } \\
\text { also reported many } \\
\text { benefits associated } \\
\text { with attending the } \\
\text { program, including being } \\
\text { more informed about } \\
\text { services, feeling more } \\
\text { supported, and being } \\
\text { more prepared. For many } \\
\text { family carers, time was } \\
\text { the main obstacle to } \\
\text { attending the program } \\
\text { due to work and/or family } \\
\text { commitments. It may be } \\
\text { that a shorter version of } \\
\text { the program could be } \\
\text { offered or, alternatively, a } \\
\text { multimedia version } \\
\text { of the program could be } \\
\text { developed for carers to } \\
\text { watch at a convenient time }\end{array}$ & $\begin{array}{l}\text { Low } \\
\text { risk }\end{array}$ \\
\hline
\end{tabular}

Results

\section{Search results}

A total of 1495 studies were identified for inclusion in the review. After removing duplicates, 1210 remained. Of these, 1009 studies were discarded at an abstract level. The remaining 181 citations were examined at the full-text level. One hundred seventythree studies did not meet inclusion criteria, yielding eight included papers. The most common reason for exclusion at the full-text level included did not investigate palliative care education for enhancing caregivers' skills in caring for terminally ill patients. PRISMA flow diagram is available in Figure 1.

\section{Characteristics of included studies}

Four papers focused on educational initiatives for family caregivers [21], [22], [23], [24] and four papers included patients and caregivers [25], [26], [27], [28].

Four studies are from the [25], [26], [27], [28], two from Australia [21], [23], one from Africa [24], and one from Taiwan [22]. The geographical spread highlights the worldwide attention to palliative care and the achievements in implemented education initiatives.

\section{Modes of delivery and duration}

There was a diverse variation in the mode of delivery and duration of educational input. Different courses have been identified using educational input following or adapting previously published 


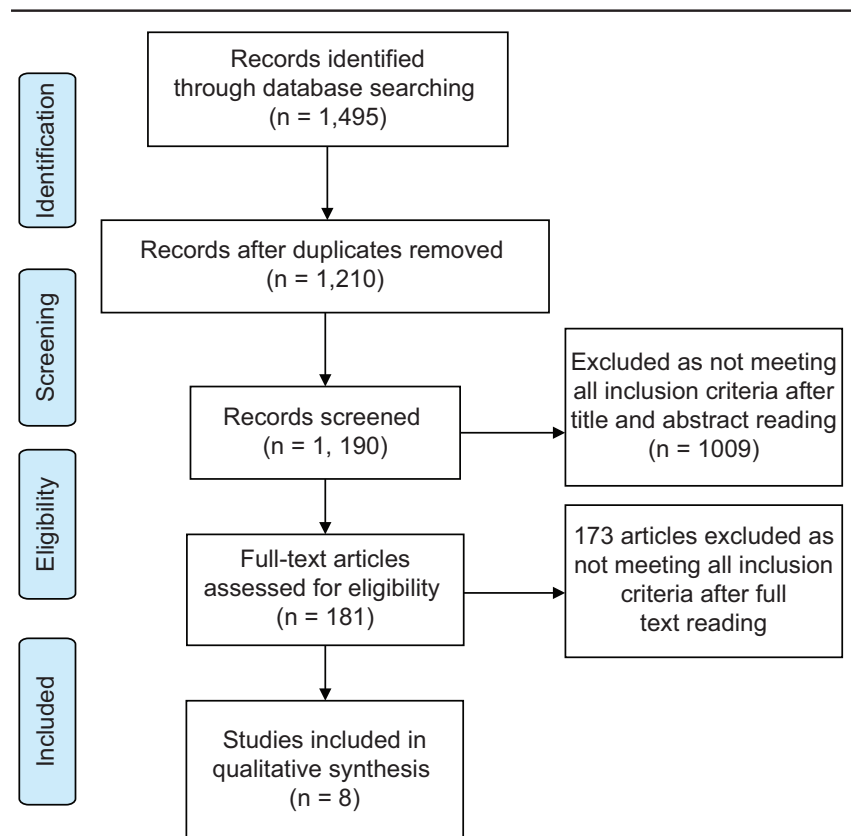

Figure 1: Preferred reporting items for systematic reviews and metaanalyses flow chart

curriculum guidelines-none of the research initiatives reported how recruitment figures were calculated. The "course delivery mode" presented blended learning [25], distance learning [21], one-on-one training sessions [22], [24], [26], [27], [29], and a mix of presentation and group work [23]. Duration has been inconsistent with the number of hours throughout the different courses; the length of study session attendance ranged from $45 \mathrm{~min}$ to $4 \mathrm{~h}$. Face-to-face sessions or placements presented an unknown extent.

\section{Teaching and learning strategies}

The studies provide insight into teaching and learning practices via the lens of a "lesson plan". These were separated into lectures emphasizing an explanatory approach, discussion groups, simulation training, videos, and workbooks. Several studies have indicated that information on teaching and learning practices is not widely shared.

\section{The focus of education input}

The programs offered an insight into the main elements of working with individuals at a palliative care bundle. Patient-centered topics included symptom management, communication, and complex interactions; nutrition and hydration; elimination; spirituality and bereavement, and dying and cultural complexity.

\section{Means of evaluating learning and feature outcomes}

Three studies were mixed-method studies [21], [23], [25], one intervention study used pretest-posttest [24], [26], [27], one study used twogroup comparative design [22], and one study used a two-armed, randomized controlled trial [27]. As a measure, scales and questionnaires were tested previously by other authors but other settings or cultures, interviews, and focus groups. Most studies reported that participants improved their knowledge, self-efficacy, and competency and prepared for their roles. Three research incorporated qualitative data in written responses from participants [23], [25], [30]. Making skilled, evidencebased, culturally sensitive cancer information and assistance more accessible to family members can alleviate co-survivors stress and allow them to more readily and effectively aid their disease loved ones [26].

\section{Discussion}

In general, the content of these courses tended to incorporate parts of care that have been suggested in policy documents such as the EAPC [12], [13], the WHO [11], and other organizations [31], which is a favorable consequence. The engagement of family members as caregivers, on the other hand, is underreported in the development of the content. Educational programs must include a focus on family carers. While palliative care initiatives have grown in popularity, family caregiver challenges have received little attention. In addition, only a few studies have shown that a comprehensive education enhancement improved the ability to give extraordinary, compassionate palliative care regardless of geography, financial situation, political views, religion, race, or ethnic origin.

Even though most palliative care education programs included pretest and post-test results, these were associated with participants' improvements in caring for cancer patients. Only a few research attempted to determine what participants learned. The most frequently measured outcomes in palliative care were knowledge, self-efficacy, and preparedness. The majority of research found an improvement in knowledge and self-efficacy among participants. However, only a few research studies conducted a follow-up study to examine the implementation of learning to practice. It is essential to consider the educational impact that these programs have on caregiver practice. The time it will take for the changes to take effect is unknown [16].

Our findings should be evaluated in light of the study's limitations, which we have identified. Metaanalysis or meta-synthesis could not synthesize the results because of the heterogeneity in delivery model, length, and outcome variables among studies. A random allocation was employed in only one trial. As a result, many studies were prone to selection bias, which led to overestimating intervention effects. Despite this, they continue to provide helpful information. 


\section{Conclusion}

Our findings point to various areas where more research should be done. Randomized controlled trials with rigorous randomization processes, more significant sample numbers and more appropriate control groups focused explicitly on caregiver education may improve the evidence. These studies should also collect data on how the instructional program affects changes in caregiver practice. Development of standardized and validated instruments to measure impact in practice, employing pretest and post-test or post-tested time-series designs, should be further researched. Furthermore, new activities related to cost-effectiveness and short- and long-term clinical effects are required. Despite the progress made in establishing an evidence base for caregivers in palliative care and respect for cultural diversity, palliative care requires specific resources as well.

\section{Implications}

The findings indicate the need for more regular and reliable palliative education programs. Discussions about educational material in this care area can also be bolstered by increased attempts to foster multimodal learning. Increased participation of the general public and service users in curriculum creation could improve the relevance of courses even further. An education and training program that is tailored to a particular purpose and practice is required. Gaps in caregiver training must be discovered, analyzed, and filled in to achieve this goal. More studies should be conducted to broaden our understanding and fill these gaps. Only then can we have a positive impact on future palliative care services. The dissemination of existing projects can aid in the development of a greater understanding of this topic.

\section{Authors Contributions}

CE contributed to the conception, study design and manuscript drafting. All authors contributed to data collection and data analysis, the absolute agreement and kappa statistics have been calculated for each data extraction category by two of the researchers. All authors read and approved the final version of the manuscript.

\section{References}

1. Page AE, Adler NE. Cancer Care for the Whole Patient: Meeting Psychosocial Health Needs. Washington, DC: National
Academies Press; 2008

2. Kim Y, Schulz R. Family caregivers' strains: Comparative analysis of cancer caregiving with dementia, diabetes, and frail elderly caregiving. J Aging Health. 2008;20(5):483-503. https:// doi.org/10.1177/0898264308317533

PMid: 18420838

3. Schumacher KL, Koresawa S, West C, Hawkins C, Johnson C Wais $\mathrm{E}$, et al. Putting cancer pain management regimens into practice at home. J Pain Symptom Manage. 2002;23(5):369-82. https://doi.org/10.1016/s0885-3924(02)00385-8

PMid:12007755

4. Sutton LM, Clipp EC, Winer EP. Management of the terminally ill patient. In: Cancer in the Elderly. Florida, United States: CRC Press; 2000. p. 549-78.

5. Given B, Sherwood PR. Family care for the older person with cancer. Semin Oncol Nurs. 2006;22(1):43-50. https://doi. org/10.1016/j.soncn.2005.10.006

PMid:16458182

6. Scherbring M. Effect of caregiver perception of preparedness on burden in an oncology population. Oncol Nurs Forum. 2002;29(6):E70-6. https://doi.org/10.1188/02.ONF.E70-E76 PMid:12096297

7. Hodges LJ, Humphris GM, Macfarlane G. A metaanalytic investigation of the relationship between the psychological distress of cancer patients and their carers. Soc Sci Med. 2005;60(1):1-12. https://doi.org/10.1016/j. socscimed.2004.04.018

PMid:15482862

8. Silva AL, Teixeira HJ, Teixeira MJ, Freitas $\mathrm{S}$. The needs of informal caregivers of elderly people living at home: An integrative review. Scand J Caring Sci. 2013;27(4):792-803. https://doi.org/10.1111/scs.12019

PMid:23289859

9. Sarmento VP, Gysels M, Higginson IJ, Gomes B. Home palliative care works: But how? A meta-ethnography of the experiences of patients and family caregivers. BMJ Support Palliat Care. 2017;7(4):1. https://doi.org/10.1136/bmjspcare-2016-001141 PMid:28232515

10. Kristanti MS, Setiyarini S, Effendy C. Enhancing the quality of life for palliative care cancer patients in Indonesia through family caregivers: A pilot study of basic skills training. BMC Palliat Care. 2017;16(1):4. https://doi.org/10.1186/s12904-016-0178-4 PMid:28095837

11. World Health Organization. Strengthening of palliative care as a component of integrated treatment throughout the life course. J Pain Palliat Care Pharmacother. 2014;28(2):130-4. https://doi. org/10.3109/15360288.2014.911801

PMid:24779434

12. Gamondi C, Larkin PJ, Payne S. Core competencies in palliative care. Eur J Palliat Care. 2013;20(2):86-91.

13. Gamondi C, Larkin P, Payne S. Core competencies in palliative care: An EAPC white paper on palliative care education-part 2. Eur J Palliat Care. 2013;20:140-5

14. Wolff JL, Spillman BC, Freedman VA, Kasper JD. A national profile of family and unpaid caregivers who assist older adults with health care activities. JAMA Intern Med. 2016;176(3):372-9. https://doi.org/10.1001/jamainternmed.2015.7664 PMid:26882031

15. Michel N, Cater III JJ, Varela O. Active versus passive teaching styles: An empirical study of student learning outcomes. Hum Resour Dev Q. 2009;20(4):397-418.

16. Smith R. Measuring the social impact of research. BMJ 2001;323(7312):528. https://doi.org/10.1136/bmj.323.7312.528 
PMid: 11546684

17. Given BA, Reinhard SC. Caregiving at the end of life: The challenges for family caregivers. Generations. 2017;41(1):50-7.

18. Network E. The EQUATOR Network, Enhancing the Quality and Transparency of Health Research; 2018. Available from: http// www equator-network org [Last accessed on 2018 Apr 23].

19. Shamseer L, Moher D, Clarke M, Ghersi D, Liberati A, Petticrew M, et al. Preferred reporting items for systematic review and metaanalysis protocols (PRISMA-P) 2015: Elaboration and explanation. BMJ. 2015;350:g7647. https://doi.org/10.1136/bmj.g7647 PMid:25555855

20. Arksey H, O'Malley L, Baldwin S, Harris J, Newbronner E, Hare P, et al. Services to Support Carers of People with Mental Health Problems. United Kingdom: Social Policy Research Unit, University of York; 2002.

21. Forbat L, Haraldsdottir E, Lewis M, Hepburn K. Supporting the provision of palliative care in the home environment: A proofof-concept single-arm trial of a PalliativE Carers Education Package (PrECEPt). BMJ Open. 2016;6(10):e012681. https:// doi.org/10.1136/bmjopen-2016-012681 PMid:27798016

22. Lee KC, Yiin JJ, Chao YF. Effect of integrated caregiver support on caregiver burden for people taking care of people with cancer at the end of life: A cohort and quasi-experimental clinical trial. Int J Nurs Stud. 2015;56:17-26. https://doi.org/10.1016/j. ijnurstu.2016.01.002 PMid:26794928

23. Hudson P, Thomas T, Quinn K, Cockayne M, Braithwaite M. Teaching family carers about home-based palliative care: Final results from a group education program. J Pain Symptom Manage. 2009;38(2):299-308. https://doi.org/10.1016/j. jpainsymman.2008.08.010

PMid: 19345553

24. Kizza IB, Muliira JK. The influence of a home-based education intervention on family Caregivers' knowledge and self-efficacy for cancer pain management in adult patients within a resourcelimited setting. J Cancer Educ. 2019;34(6):1150-9. https://doi. org/10.1007/s13187-018-1421-x

PMid:30187440
25. Bender JL, Flora PK, Milosevic E, Soheilipour S, Maharaj N, Dirlea $\mathrm{M}$, et al. Training prostate cancer survivors and caregivers to be peer navigators: A blended online/in-person competency-based training program. Support Care Cancer. 2021;29(3):1235-44. https://doi.org/10.1007/s00520-020-05586-8 PMid:32613373

26. Marshall CA, Badger TA, Curran MA, Koerner SS, Larkey LK, Weihs KL, et al. Un abrazo para la familia: Providing low-income hispanics with education and skills in coping with breast cancer and caregiving. Psychooncology. 2013;22(2):470-4. https://doi. org/10.1002/pon.2108

PMid:22140003

27. Hendrix CC, Landerman R, Abernethy AP. Effects of an individualized caregiver training intervention on self-efficacy of cancer caregivers. West J Nurs Res. 2013;35(5):590-610. https://doi.org/10.1177/0193945911420742 PMid:21949091

28. Hendrix CC, Abernethy A, Sloane R, Misuraca J, Moore J. A pilot study on the influence of an individualized and experiential training on cancer Caregiver's self-efficacy in home care and symptom management. Home Healthc Nurse. 2009;27(5):271-8. https://doi.org/10.1097/01.nhh.0000356777.70503.62 PMid:19448494

29. Hendrix CC, Ray C. Informal caregiver training on home care and cancer symptom management prior to hospital discharge: A feasibility study. Oncol Nurs Forum. 2006;33(4):793-8. https:// doi.org/10.1188/06.ONF.793-798

PMid:16858461

30. Forbat L, Robinson R, Bilton-Simek R, Francois K, Lewis $M$, Haraldsdottir E. Distance education methods are useful for delivering education to palliative caregivers: A single-arm trial of an education package (PalliativE Caregivers Education Package). Palliat Med. 2018;32(2):581-8. https://doi. org/10.1177/0269216317712849

PMid:28604233

31. Cengic T, Brkljacic M, Turina IS, Corluka S, Mavrinac M, Rotim A, et al. Can croatian medicine do without palliative medicine? Study investigating the need for formal education. Coll Antropol. 2013;37:1133-7.

PMid:24611325 